\title{
Effect of Organic Manure on Nitrogen Mineralization, Nitrogen Accumulation, Nitrogen Use Efficiency and Apparent Nitrogen Recovery of Cauliflower (Braccica oleracea L., var. Botrytis)
}

\author{
A. A. Beah ${ }^{1}$, P. E. Norman ${ }^{1 *}$, J. C. Scholberg ${ }^{2}$, E. A. Lantinga ${ }^{2}$ and A. R. Conteh ${ }^{1}$ \\ ${ }^{1}$ Njala Agricultural Research Center (NARC), Sierra Leone Agricultural Research Institute (SLARI), \\ PMB 540, Freetown, Sierra Leone. \\ ${ }^{2}$ Farming Systems Ecology, Wageningen University, 6708 PB, Wageningen, Netherlands.
}

\section{Authors' contributions}

This work was carried out in collaboration between all authors. Author AAB contributed in designing and conducting the experiment. Authors PEN and ARC contributed in designing, statistical analysis and report writing, authors JCS, EAL contributed in designing, monitoring the experiment. All authors read and approved the final manuscript.

Article Information

DOI: $10.9734 / I J P S S / 2015 / 12660$ Editor(s):

(1) Anonymous.

(2) Sławomir Borek, Faculty of Biology, Department of Plant Physiology, Adam Mickiewicz University, Poland.

Reviewers:

(1) Guangwei Huan, Graduate School of Global Environmental Studies, Sophia University, Japan.

(2) Luigi Morra, National Council for Agricultural Research (CRA) - Unit for Alternative Crops to tobacco, Scafati (Salerno),
Italy.

(3) Anonymous, University of Ouagadougou, Burkina Faso. (4) Anonymous, CSIR-Food Research Institute, Accra, Ghana. (5) Anonymous, Amity University Uttar Pradesh, India. Complete Peer review History: http://www.sciencedomain.org/review-history.php?iid=704\&id=24\&aid=6552

\section{ABSTRACT}

Aims: The main aim of the study was to assess the effects of organic manure on nitrogen mineralization, uptake, use and recovery of cauliflower.

Methodology: Nitrogen is one of the major yield limiting nutrients in cauliflower production. However, organic manure is applied to supplement soil nitrogen supply to maximize dry-matter yield. A field experiment was conducted at the Droevendaal Certified Organic Research and Demonstration Site of Wageningen University, Netherlands during 2012. The experiment was laid out in a randomized complete block design with four replications. The treatments comprised of four 
rates $\left(0,75,150\right.$ and $\left.225 \mathrm{kgN} \mathrm{ha}^{-1}\right)$ each of lucerne pellets (LUP) and dry grass clover (DGC) organic manures.

Results: Results showed that LUP amended plots exhibited highest initial N-mineralization compared to DGC and control plots. Nitrogen uptake in plant organs increased with increasing organic manure application. Nitrogen accumulation was highest in cauliflower leaf $\left(38.28 \mathrm{mg} \cdot \mathrm{kg}^{-1}\right)$, followed by the head $\left(16.96 \mathrm{mg} \cdot \mathrm{kg}^{-1}\right)$ and lowest in the stem $\left(3.01 \mathrm{mg} \cdot \mathrm{kg}^{-1}\right)$.

Conclusion: Results suggest that timely and adequate nitrogen release from organic manures is important for the success of conservation and sustainable farming systems. Findings in this study could be utilized in improving efficiency of $\mathrm{N}$ use in crop management rotation systems.

Keywords: Organic manure; mineralization; uptake; accumulation; cauliflower.

\section{INTRODUCTION}

Vegetable production is often associated with excessive use of nitrogen fertilizer resulting in large mineral $\mathrm{N}$ residues in the soil and crop [1]. The increasing use of nitrogen excites soil microbial metabolism and enzymes [2]. However, excessive $\mathrm{N}$ fertilization may result in adverse environmental and economic effects such as accelerated $\mathrm{N}_{2} \mathrm{O}$ gas emission, $\mathrm{NO}_{3}^{-}$leaching and higher cost of production [1].

Mineralization processes are significant, particularly in soils affected by long term cultivation and different cropping practices [3]. During mineralization of organic manures, additional mineral $\mathrm{N}$ is released into the soil, resulting in large nitrate residues in the soil. Mineralization contributes more to high nitrate leaching especially in autumn and winter [1]. Soil mineral $\mathrm{N}$ content is believed to increase following harvesting of vegetables [4]. Residues of cauliflower vegetables were observed to contain between 80 and $120 \mathrm{~kg} \mathrm{~N}^{-1}$ [5]. Soil tillage and crop residue management practices were reported to influence microbial population, activity, carbon and nitrogen mineralization dynamics, and plant biomass [6].

Nitrogen use efficiency consists of two main concepts including $\mathrm{N}$ uptake efficiency and $\mathrm{N}$ utilization efficiency. The $\mathrm{N}$ uptake efficiency is the ability of crops to take up $\mathrm{N}$ from the soil [7], while the utilization efficiency of the absorbed N, is the efficiency with which absorbed $\mathrm{N}$ are used to enhance growth and yield of crops [8]. Both efficiencies may vary within the same crop since they are dependent on different organs, mechanisms and environmental factors [8]. Several factors have been reported to cause low $\mathrm{N}$ use efficiency in the soil-plant systems [9]. These include volatilization of ammonia $\left(\mathrm{NH}_{3}\right)$, leaching of nitrate $\left(\mathrm{NO}_{3}{ }^{-}\right)$, denitrification and soil erosion [9]. Nitrogen use efficiency of crops can be improved through adoption of adequate management practices. Use of adequate amount of nitrogen manures, forms and methods of application are important management strategies for good crop growth and development [10].

Crop nitrogen uptake from the soil is a function of two recovery factors including fertilizer- $\mathrm{N}$ and soil-N. Knowledge of these two recovery factors is needed since soil- $\mathrm{N}$ and fertilizer-N may not be available at the same time and space [7]. Moreover, knowledge of available nitrogen in organic manures is also imperative to improve nitrogen use efficiency and to reduce the pressure of agriculture on the environment [11]. Not all nitrogen taken up by crops ends up in harvestable produce. In cauliflower, for instance, about $50 \%$ of total $\mathrm{N}$ uptake is utilized to produce economic yield, while $50 \%$ remains in the field as crop residues [5]. The main objective of the study was to assess the effect of organic fertilization on nitrogen mineralization, nitrogen use efficiency and apparent nitrogen recovery of cauliflower.

\section{MATERIALS AND METHODS}

\subsection{Experimental Site Description}

This study was conducted at the Droevendaal Certified Organic Research and Demonstration Site of Wageningen University, Netherlands, to evaluate the effect of organic manure on nitrogen accumulation, nitrogen use efficiency and apparent nitrogen recovery of cauliflower from late June to early October 2012. The mean annual temperature and precipitation of the study area were $11^{\circ} \mathrm{C}$ and $829 \mathrm{~mm}$, respectively.

\subsection{Treatments, Experimental Design and Field Management}

A total of eight treatments consisting of dried grass clover (DGC) applied at four rates $(0,75$, 150 and $225 \mathrm{~kg} \mathrm{~N} \mathrm{ha}^{-1}$ ) were compared with the same rates of Lucerne pellets (LUP). 
The grass clover was dried for two days before application. One white cauliflower variety, snowball, was used. The experiment was laid in a Randomized Complete Block Design (RCBD) with four replications. A plot size of $3 \times 3 \mathrm{~m}$ was used. The soil amendments were applied one day before transplanting at $50 \times 60 \mathrm{~cm}$ apart giving a density of 30 plants per plot $(33,333$ plants $\mathrm{ha}^{-1}$ ). Cauliflower seedlings were transplanted in late June and harvested in early October 2012. Weeding was done manually by hoeing when necessary. No pesticide was used.

\subsection{Soil Sampling}

A Jarret T-handle soil auger $(100 \mathrm{~mm}$ head diameter) was used to collect soil samples prior to establishment of the experiment in late June 2012. Twenty samples were randomly collected per plot using repeated soil coring from $0-30$ and $30-60 \mathrm{~cm}$ soil depth and composited for analysis. Fresh soil samples were first sieved using $8-\mathrm{mm}$ grid size to remove plant residues, roots and stones, and dried in a forced-air oven at $75^{\circ} \mathrm{C}$ for $24 \mathrm{~h}$ until consistent mass was attained. Dried soil samples were further sieved after cooling using 2-mm grid size for chemical analysis. Similar protocols were used for soil samples collected at 3, 5, 9 and 13 weeks after transplanting (WAT) from $0-30 \mathrm{~cm}$ soil depth. Samples were collected at a $5-10 \mathrm{~cm}$ radius from growing plants. At harvest, soil samples were collected from 0-30 and $30-60 \mathrm{~cm}$ soil depths for the determination of residual soil mineral $\mathrm{N}$. The later depth was done to determine the amount of nitrogen that leached beyond the rooting zone.

\subsection{Nitrogen Mineralization}

About $300 \mathrm{mg}$ of oven-dried soil taken at different sampling regimes for each organic treatment was used for total $\mathrm{N}\left(\mathrm{NH}_{4}{ }^{+}\right.$and $\left.\mathrm{NO}_{3}{ }^{-}\right)$determination as described by [12]. Each soil sample was heated to $100^{\circ} \mathrm{C}$ for $2 \mathrm{~h}$ after addition of $\mathrm{H}_{2} \mathrm{SO}_{4}$ Se. After cooling, $1 \mathrm{M} \mathrm{H}_{2} \mathrm{O}_{2}$ was added drop-wise and the content heated again to $340^{\circ} \mathrm{C}$ for about $2 \mathrm{~h}$. The content was then diluted with distill water to $50 \mathrm{ml}$, and analyzed for total $\mathrm{N}$ using the steam-distillation method in a spectrophotometer. Nitrogen mineralization was determined based on [13] as below:

$$
\begin{aligned}
& N \text {-net mineralization }=\text { total plant } N \text { uptake }+N_{\text {min }} \\
& \text { residue at harvest }-N_{\text {min }} \text { at planting }
\end{aligned}
$$

Where total plant $\mathrm{N}$ uptake = above-ground $\mathrm{N}$ accumulation in stems, leaves and heads calculated after determination of dry weight and
$\mathrm{N}$ content in the different plant organs excluding the roots [14]. Similarly, the recovery $N$ efficiency was calculated based on the formula used by [14].

\subsubsection{Nitrogen-use metrics}

Nitrogen use in relation to dry matter yield was determined using nitrogen use efficiency (NUE) and apparent nitrogen recovery (ANR).

Nitrogen use efficiency (mass of biomass per mass of $\mathrm{N}$ ) for each harvest was calculated as $[15,16]$ :

$$
\begin{gathered}
N U E=\left(\text { yield at } N_{x}-\text { yield at } N_{0}\right) / \text { mass of } N \\
\text { applied. }
\end{gathered}
$$

Where $\mathrm{N}_{\mathrm{x}}=\mathrm{x}$ amount of $\mathrm{N}$ applied, and $\mathrm{N}_{0}=\mathrm{no}$ $\mathrm{N}$ applied.

Apparent nitrogen recovery (\%) for each harvest was calculated using the $\mathrm{N}$ difference method [17]:

$$
\operatorname{ANR}(\%)=\left[\left(T N U_{x}-T N U_{0}\right) / T N A\right] \times 100 .
$$

Where $\mathrm{TNU}_{\mathrm{x}}=$ the total plant $\mathrm{N}$ uptake from the manure treated plots, $\mathrm{TNU}_{0}=$ total plant nitrogen uptake from the control plot and TNA = total manure $\mathrm{N}$ applied.

\subsection{Manure Sample Analysis}

Prior to application of dry grass clover and lucerne pellet, the manures were independently analyzed for dry matter content (DM), total $\mathrm{N}$ $\left(\mathrm{N}_{\text {tot }}\right)$, mineral $\mathrm{N}\left(\mathrm{N}_{\min }\right), \mathrm{P}_{2} \mathrm{O}_{5}$ and $\mathrm{K}_{2} \mathrm{O}$ as described in previous papers [18,19]. Manure samples were prepared and analyzed according to the procedures described by [12].

\subsection{Plant Organ Analysis}

At harvest, the 6 tagged plants randomly selected in the experimental plots were cut at soil level for above plant organ analysis using secateurs. Fresh biomass from each plot was separated into leaves, stems and head organs. Samples were oven-dried at $105^{\circ} \mathrm{C}$ for $48 \mathrm{~h}$, weighed, ground and sieved using $1 \mathrm{~mm}$ sieve. Total $\mathrm{N}$ in organs was measured after wet decomposition as described by [20]. Total $\mathrm{N}$ uptake for each plant organ was estimated by multiplying DM yield of plant organ with its $\mathrm{N}$ content. 


\subsection{Data Analysis}

Data were subjected to analysis of variance (ANOVA) using the GENSTAT statistical programme (GENSTAT, $15^{\text {th }}$ release, Rothampstead, UK). Mean separation was done using the Duncan's Multiple Range Test (DMRT). The residuals of data for the parameters used were first checked for normality and homogeneity using the Shapiro-Wilk test and Bartlett's test to ensure that data were normally distributed.

\section{RESULTS AND DISCUSSION}

\subsection{Soil and Organic Manure Analyses}

The LUP manure had higher dry matter and total $\mathrm{N}$ than DGC (Table 1). Dried grass clover exhibited longer decomposition time and higher $\mathrm{C} / \mathrm{N}$ ratio compared to LUP). The $\mathrm{P}_{2} \mathrm{O}_{5}$ and $\mathrm{K}_{2} \mathrm{O}$ contents were higher in DGC than in LUP.

\section{Table 1. Mean dry matter (DM) content and chemical composition of plant-based fertilizers}

\begin{tabular}{llllll}
\hline $\begin{array}{l}\text { Plant-based } \\
\text { manures }\end{array}$ & $\begin{array}{l}\mathrm{DM} \\
(\%)\end{array}$ & $\mathbf{C} / \mathbf{N}^{1}$ & $\begin{array}{l}\mathbf{N}_{\text {tot }} \\
(\%)\end{array}$ & $\begin{array}{l}\mathbf{P}_{2} \mathbf{O}_{5} \\
(\%)\end{array}$ & $\begin{array}{l}\mathbf{K}_{2} \mathbf{O} \\
(\%)\end{array}$ \\
\hline $\begin{array}{l}\text { Dried grass- } \\
\text { clover }\end{array}$ & 55.6 & 23.2 & 1.9 & 0.4 & 2.4 \\
\begin{tabular}{l} 
Lucerne pellet \\
\multicolumn{1}{c}{$\mathrm{C} / \mathrm{N}$ ratio are based on a carbon content of $44 \%$}
\end{tabular}
\end{tabular}

\subsection{Soil Mineral N Measured During the Growing Season}

The effect of manure type and rate on $\mathrm{N}$ mineralization during various sampling regimes is shown in Fig. 1. Generally, N-mineralization increased with increasing organic manure application. Lucerne pellet amended plots significantly $(\mathrm{P}<0.05)$ exhibited highest initial $\mathrm{N}$ mineralization compared to DGC and control plots. At 3 WAT, LUP application at 150-225 N kg.ha ${ }^{-1}$ produced higher total soil mineral $\mathrm{N}$ ranging from $42.02-44.88 \mathrm{mg} . \mathrm{kg}^{-1}$ compared to the remaining treatments. At 9 WAT, DGC plots produced significantly higher total soil mineral $\mathrm{N}$ ranging from $5.42-6.05 \mathrm{mg}^{-1} \mathrm{~kg}^{-1}$ than the control $\left(3.35 \mathrm{mg} \cdot \mathrm{kg}^{-1}\right)$. At 13 WAT, the non-amended plot had similar soil mineral $\mathrm{N}$ as most of the treatments, except for the 150 and 225kg.N.ha ${ }^{-1}$ LUP amended plots. The lower soil mineral- $\mathrm{N}$ in DGC amended plots gives an indication of an initial increase in microbial $\mathrm{N}$-immobilization.
Several authors also support this notion [21-23]. The slow growth of cauliflower in DGC amended plots may be attributed to the high $\mathrm{C} / \mathrm{N}$ (23.2) ratio (Table 2), leading to lower soil $\mathrm{N}$ concentration as microbes competed with roots for $\mathrm{N}$ uptake [24]. Li et al. [25] noted that the cumulative mineralization of organic $\mathrm{N}$ and $\mathrm{C}$ increased as paddy soil fertility levels increased. Furthermore, [22] observed greater N mineralization in unfertilized winter wheat plots compared to the fertilized plots. This is partly consistent with soil mineral $\mathrm{N}$ content observed at 13 WAT.

The initial composition of the soil prior to planting is shown in Table 2.

Table 2. Composition of soil before planting

\begin{tabular}{lll}
\hline & $\begin{array}{l}\text { 0-30cm } \\
\text { soil depth }\end{array}$ & $\begin{array}{l}\text { 30-60cm } \\
\text { soil depth }\end{array}$ \\
\hline $\mathrm{N}_{\text {tot }}(\%)$ & 0.1 & ${ }^{*}$ \\
$\mathrm{Nmin}\left(\mathrm{kg} \mathrm{ha}^{-1}\right)$ & 48 & 32 \\
$\mathrm{pH}(\mathrm{KCl})$ & 5.4 & 5.6 \\
$\mathrm{Bulk}$ density $\left(\mathrm{kg} \mathrm{dm}^{-1}\right)$ & 1.5 & 1.5 \\
$\mathrm{SOC}(\%)$ & 1.8 & $*$ \\
\hline${ }^{*}=$ not determined, $N$ tot=total nitrogen, $\mathrm{N}$-min=nitrogen \\
\multicolumn{2}{c}{ mineralization, SOC=soil organic carbon }
\end{tabular}

\subsection{Nitrogen Accumulation and Nitrogen Use Efficiency (NUE)}

Total $\mathrm{N}$ uptake of cauliflower plants increased with increasing organic manure application (Table 3; Fig. 2). Treatment LUP 225 exhibited significantly highest amount of total $\mathrm{N}$ uptake compared to DGC 75 and non-amended or control treatments. The early mineralization and higher uptake in LUP amended plots enhanced higher dry matter yield compared to other treatments as previous reported [19].

Both organic manure type and rate significantly $(p<0.05)$ affected nitrogen accumulation in cauliflower leaf, stem and head organs (Table 3). Nitrogen accumulation in all organs increased with increasing organic manure application. Nitrogen accumulation was highest in cauliflower leaf $\left(38.28 \mathrm{mg}^{-1} \mathrm{~kg}^{-1}\right)$, followed by the head $\left(16.96 \mathrm{mg}^{-1} \mathrm{~kg}^{-1}\right)$ and lowest in the stem $\left(3.01 \mathrm{mg} . \mathrm{kg}^{-1}\right)$. The higher nitrogen intake in the various organs is indicative of the enhanced growth and increased yield in the organic amended plots compared with the non-amended plots [22,23]. 


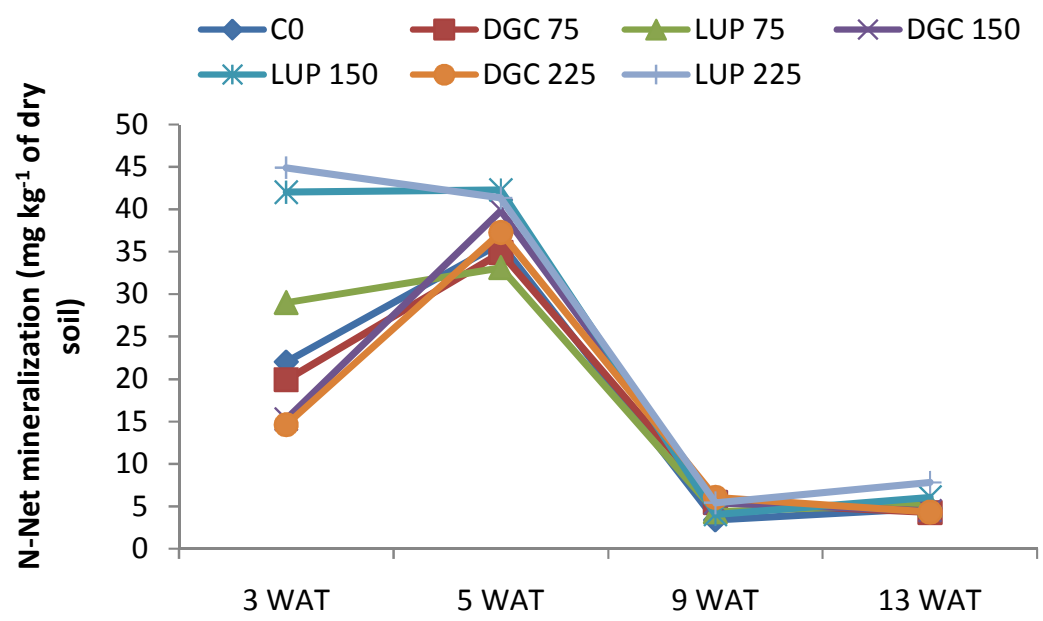

Sampling time (weeks after transplanting)

Fig. 1. Effect of manure application on $\mathrm{N}$-mineralization across various sampling regimes $C O=$ control plot with zero manure application, $D G C=d r y$ grass clover, $L U P=l u c e r n e ~ p e l l e t$, each applied at 75 , 150 and 225kg.N.ha ${ }^{-1}$

Unlike total $\mathrm{N}$ uptake in various cauliflower organs, NUE decreased with increasing organic manure application (Table 3). Findings are in agreement with [26], who observed increased shoot $\mathrm{N}$ accumulation and decreased NUE with increasing $\mathrm{N}$ rate in pepper, tomato and lettuce. Quanbao et al. [27] also noted that nitrogen use efficiency of genotypes significantly decreased as $\mathrm{N}$ application increased. The decreasing NUE may be partly due to environmental influence on crop growth and development or the $\mathrm{N}$ availability from the soil through effects on mineralization of soil organic matter, organic manures and on nitrate leaching [28].

Total $\mathrm{N}$ in soil residue at harvest significantly increased with increasing organic application (Fig. 2). Nitrogen concentration in LUP residues was higher than DGC amended plants, resulting in lower $\mathrm{C} / \mathrm{N}$ ratio. Application at 150-225.
kg.N.ha ${ }^{-1}$ LUP left a considerable amount of mineral $\mathrm{N}$ in the soil at harvest compared to the remaining treatments. The high $\mathrm{N}$ release from LUP amended plots compared to non-amended.

plots was indicative of the residual effect of organic fertilization on the mineralization. Similarly, [1] also noted more nitrogen in artichoke residues with higher $\mathrm{N}$ application than lower application rates.

\subsection{Apparent Nitrogen Recovery (ANR)}

Apparent nitrogen recovery deceased linearly with a unit increase in $\mathrm{N}$ application rate (Fig. 3). Apparent nitrogen recovery was consistently higher in LUP than DGC treatments. The gap between the two manure types widens with increasing $\mathrm{N}$ rate.

Table 3. Effect of manure application on $\mathbf{N}$ accumulation in leaf, stem and head organs and NUE of cauliflower

\begin{tabular}{|c|c|c|c|c|c|c|c|c|}
\hline \multirow[t]{2}{*}{$\mathrm{N}$ rate $\left(\mathrm{kg} \cdot \mathrm{ha}^{-1}\right)$} & \multicolumn{2}{|c|}{$\begin{array}{l}\text { Leaf } \mathrm{N} \text { uptake } \\
\left(\mathrm{mg} \cdot \mathrm{kg}^{-1}\right)\end{array}$} & \multicolumn{2}{|c|}{$\begin{array}{l}\text { Stem N uptake } \\
\left(\mathrm{mg}^{\mathrm{kgg}}{ }^{-1}\right)\end{array}$} & \multicolumn{2}{|c|}{$\begin{array}{l}\text { Head N uptake } \\
\left.\left(\mathrm{mg}^{\mathrm{kgg}}\right)^{-1}\right)\end{array}$} & \multicolumn{2}{|c|}{$\begin{array}{l}\text { Nitrogen use efficiency } \\
(\mathrm{kg} \mathrm{N})\end{array}$} \\
\hline & DGC & LUP & DGC & LUP & DGC & LUP & DGC & LUP \\
\hline 0 & $27.08^{d}$ & $27.08^{d}$ & $1.77^{\mathrm{C}}$ & $1.77^{\mathrm{C}}$ & $9.07^{d}$ & $9.07^{d}$ & & $-\infty$ \\
\hline 75 & $37.31^{\mathrm{c}}$ & $37.58^{c}$ & $2.92^{\mathrm{b}}$ & $3.06^{\mathrm{b}}$ & $17.75^{\mathrm{c}}$ & $22.38^{\mathrm{a}}$ & $223.9^{a}$ & $170.5^{\mathrm{b}}$ \\
\hline 150 & $42.75^{\mathrm{b}}$ & $43.39^{b}$ & $3.56^{\mathrm{ab}}$ & $3.44^{\mathrm{ab}}$ & $16.95^{\mathrm{c}}$ & $19.22^{b}$ & $98.1^{\mathrm{C}}$ & $105.2^{c}$ \\
\hline 225 & $44.76^{\mathrm{ab}}$ & $46.27^{\mathrm{a}}$ & $3.91^{a}$ & $3.68^{\mathrm{a}}$ & $18.59^{\mathrm{bc}}$ & $22.64^{a}$ & $79.6^{c}$ & $99.8^{\mathrm{C}}$ \\
\hline CV (\%) & 3.20 & & 5.10 & & 6.10 & & 8.1 & \\
\hline
\end{tabular}




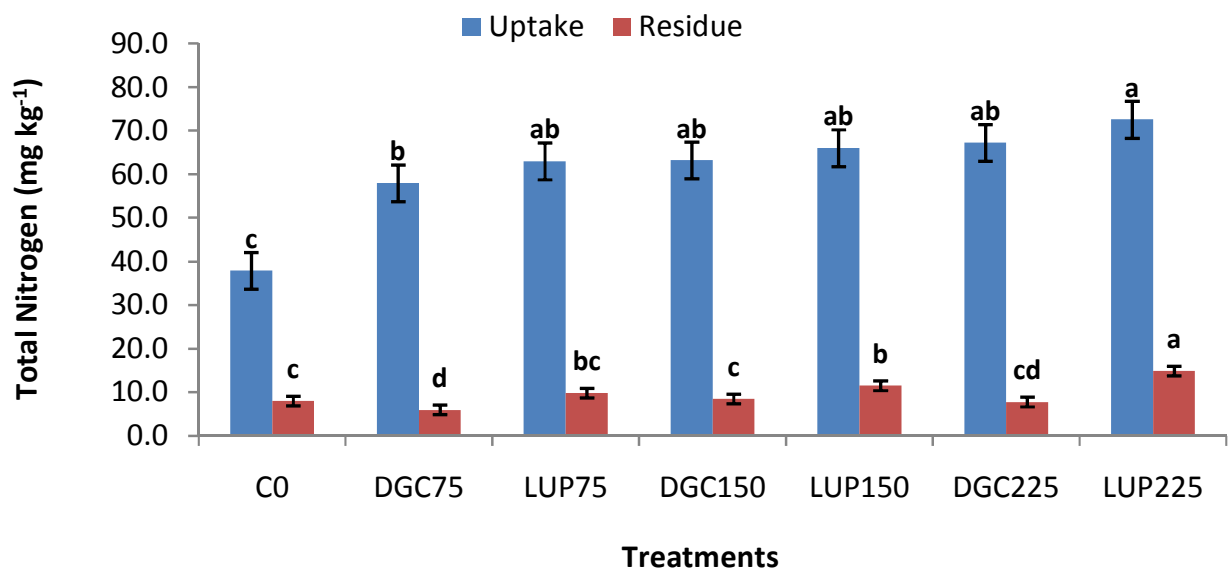

Fig. 2. Effect of nitrogen application on $\mathbf{N}$ total uptake and $\mathbf{N}$ in soil residue of dry grass clover, lucerne pellets and control plots

$C 0=$ control plot with zero manure application, $D G C=d r y$ grass clover, LUP=lucerne pellet, each applied at 75, 150 and $225 \mathrm{~kg} . \mathrm{N} \cdot \mathrm{ha}^{-1}$

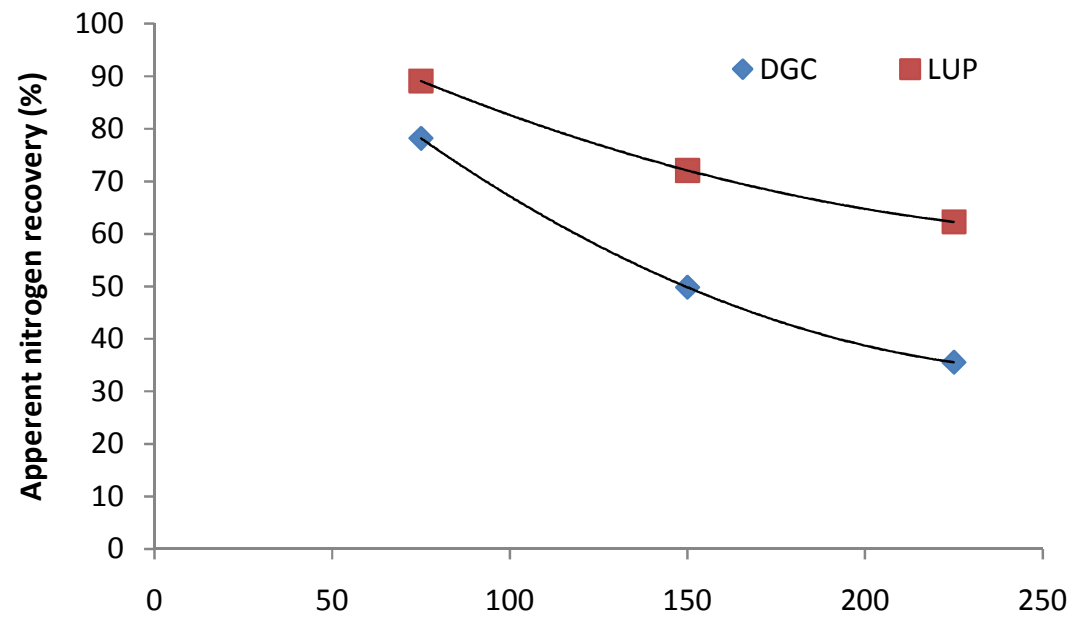

Nitrogen application rate $\left(\mathrm{kg} \mathrm{ha}^{-1}\right)$

Fig. 3. Effect of organic fertilization on apparent nitrogen recovery of botrytis. LUP=lucerne pellets and DGC=dried grass clover

The decreasing ANR as $\mathrm{N}$ application rate increased implied high nutrient demand of the cauliflower crop. Similarly, apparent nitrogen recovery was noted to decrease as $\mathrm{N}$ application rate increased [27]. Findings are also supported by the fact that crops are more efficient at recovering $\mathrm{N}$ when the fertilizer- $\mathrm{N}$ rate is relatively low [7].

\section{CONCLUSION}

Timely and adequate nitrogen release from organic manures is important to $\mathrm{N}$ management and the success of conservation and sustainable farming systems. Nitrogen immobilization in the initial period with high $\mathrm{C} / \mathrm{N}$ ratio of $\mathrm{DGC}$ manure compared to LUP was observed in this study. Nitrogen mineralization from organic manures was dependent on the initial total $\mathrm{N}$ content in the plant and chemical composition of the organic manures. Nitrogen mineralization increased with increasing $\mathrm{N}$ application. Nitrogen accumulation in above ground organs increased as $\mathrm{N}$ rate increased with leaf organ possessing highest, followed by head and the stem; while NUE decreased with increasing $\mathrm{N}$ rate in cauliflower. The ANR was higher in plots with low organic fertilization than those with high $\mathrm{N}$ applications. Findings in this study could be utilized in 
improving efficiency of $\mathrm{N}$ use in crop management rotation systems.

\section{ACKNOWLEDGEMENTS}

The authors appreciate Paul Speijer and the Anne van den Band Foundations for their financial support, and the Farming Systems Ecology of the Wageningen University, Netherlands for their technical support.

\section{COMPETING INTERESTS}

Authors have declared that no competing interests exist.

\section{REFERENCES}

1. Mahmoud EK, Abd NK, Kader EL. How the nitrogen fertilization dose affects the biochemical composition and net mineralization of the artichoke residues, Journal of Soil Science and Plant Nutrition. 2012;12(1):23-31.

2. De Neve S, Hoffman G. Quantifying soil water effects on nitrogen mineralization from soil organic matter and from fresh crop residues. Biol Fertil Soils 2002;35:379-386.

3. Qualls RG, Richardson CJ. P enrichment affects litter decomposition, immobilization, and soil microbial $P$ in wetland mesocosms. Soil Sci. Soc. Am. J. 2000;64(2):799-808.

4. De Neve S, Hofman G. N mineralization and nitrate leaching from vegetable crop residues under field conditions: A model evaluation. Soil Biol. Biochem. 1998;30(14):2067-2075.

5. Everaarts AP, De Moel CP, Van Noordwijk $M$. The effect of nitrogen and the method of application on nitrogen uptake of cauliflower and on nitrogen in crop residues and soil at harvest, Netherlands J. Agri. Sci. 1996;44(1):43-55.

6. Islam KR, Weil RR. Soil quality indicator properties in mid-Atlantic soils as influenced by conservation management. J. Soil and Water Conserv. 2000;55:69-78.

7. Burns IG. Assessing $\mathrm{N}$ fertilizer requirements and the reliability of different recommendation systems. Acta Hort. 2006;700:35-48.

8. Schenk MK. Nutrient efficiency of vegetable crops. Acta Hort. 2006;700:2538.
9. Owens VN, Viands DR, Mayton HS, Fike JH, Farris R, Heaton E, Bransby DI, Hong $\mathrm{CO}$. Nitrogen use in switch grass grown for bioenergy across the USA. Biomass and Bioenergy. 2013;58:286-293.

10. Tayefe M, Gerayzade G, Amiri E, Zade AN. Effect of nitrogen fertilizer on nitrogen uptake, nitrogen use efficiency of rice. International Conference on Biology, Environment and Chemistry IPCBEE (C) (2011) IACSIT Press, Singapoore. $2011 ; 24: 470-473$.

11. Alt $\mathrm{C}$, Kage $\mathrm{H}$, Stützel $\mathrm{H}$. Modelling Nitrogen content and distribution in cauliflower (Brassica oleracea $L$. botrytis). An. Biota. 2000;86:963-973.

12. Novozamsky I, Houba VJG, van Eck R, Vark W. A novel digestion technique for multi-element plant analysis. Com. Soil Sci. and Plant Anal. 1983;14(3):239-248.

13. Rather $K$, Schenk M, Everaarts A, Vethman S. Response of yield and quality of cauliflower varieties (Brassica oleracea var. botrytis) to nitrogen supply. J. Hort. Sci. and Biotech. 1999;74(5):658-664.

14. Cui Z, Zhang F, Chen X, Miao Y, Li J, Shi L, Xu J, Ye Y, Liu C, Yang Z. On-farm evaluation of an in-season nitrogen management strategy based on soil Nmin test. Field Crops Res. 2008;105(1-2):4855.

15. Zemenchick RA, Albrecht KA. Nitrogen use efficiency and apparent nitrogen recovery of Kentucky bluegrass, smooth bromegrass, and orchard grass. Agron J. 2002;94(3):421-428.

16. Novoa R, Loomis RS. Nitrogen and plant $p$ roduction. Plant Soil. 1981;58(1-3):177204.

17. Crasswell ET, Godwin DC. The efficiency of nitrogen fertilizers applied to cereals in different climates. In: Thinker PB, Lauchli A, editors. Advances in plant nutrition. New York: Praeger. 1984;1-55.

18. Beah AA, Norman PE, Scholberg JC, Latinga EA, Conteh AR. Effect of Green Manures on Nitrogen Uptake and Yield of Cauliflower (Brassica oleracea var. botrytis) Intern. J. Applied Agric. Res. 2014;9(1):73-84.

19. Beah AA, Norman PE, Scholberg JC, Latinga EA, Conteh AR. Effect of Organic Manure on Soil Bio-physical Properties and Dry Matter Partitioning in Cauliflower Intern. J. Plant \& Soil Sci. 2014;3(9):10441054. 
20. Houba, VJG, Van Der Lee JJ, Novozamsky I, Walinga I. Soil and plant analysis, a series of syllabi, Part 5, soil analysis proceures. Wageningen Agricultural University, Wageningen, the Netherlands; 1989.

21. Olfs HW, Blankenau K, Brentrup F, Jasper J, Link A, Lamme LJ. Soil- and plant-based nitrogen-fertilizer recommendations in arable farming. J Plant Nutrition and Soil Sci. 2005;168(4):414-431.

22. Engels $\mathrm{T}$, Kuhlmann $\mathrm{H}$. Effect of the rate of $\mathrm{N}$ fertilizer on apparent net mineralization of $\mathrm{N}$ during and after cultivation of cereal and sugar beet crops. Zeitschrift für Pflanzenernaehrung und Bodenkunde, 1993;156:149-154.

23. Fox $R$, Myers $R$, Vallis I. The nitrogen mineralization rate of legume residues in soil as influenced by their polyphenol, lignin, and nitrogen contents. Plant and Soil. 1990;129(2):251-259.

24. Nygaard Sorensen J, Thorup-Kristensen K. Plant-based fertilizers for organic vegetable production. J. Plant Nutrition and Soil Sci. 2011;174(2):321-332.
25. Li ZP, Han CW, Han FX. Organic C and N mineralization as affected by dissolved organic matter in paddy soils of subtropical China. Geoderma. 2010;157(34): 206-213.

26. Tei F, Benincasa P, Guiducci M. Nitrogen fertilization on lettuce, processing tomato and sweet pepper: Yield, nitrogen uptake and the risk of nitrate leaching. Acta Hort.1999;506:61-67.

27. Quanbao Y, Hongcheng Z, Haiyan W, Ying Z, Benfo W, Ke X, Zhongyang H, Qigen D, $\mathrm{Ke} X$. Effects of nitrogen fertilizer on nitrogen use efficiency and yield of rice under different soil conditions. Agric. China 2007;1(1):30-36.

28. Agostini $F$, Tei F, Silgram M, Farneselli $M$, Benincasa $\mathrm{P}$, Aller MF. Decreasing $N$ leaching in vegetable crops through improvements in $\mathrm{N}$ fertilizer management, Genetic engineering, biofertilisation, soil quality and organic farming, ed Lichtfouse E. (Springer, Dordrecht, The Netherlands) Sust. Agr. Rev. 2010;4:147-200.

(C) 2015 Beah et al.; This is an Open Access article distributed under the terms of the Creative Commons Attribution License (http://creativecommons.org/licenses/by/4.0), which permits unrestricted use, distribution, and reproduction in any medium, provided the original work is properly cited.

Peer-review history:

The peer review history for this paper can be accessed here: http://www.sciencedomain.org/review-history.php?iid=704\&id=24\&aid=6552 